\title{
A Kárpát-medence gazdasági és társadalmi szerkezete és kezelési lehetőségei - Egy személyes hangvételü bevezetés
}

\section{Economic and social structure of the Carpathian basin and the possibilities of their management - A personal introduction}

\author{
SZIRMAI VIKTÓRIA
}

\begin{abstract}
SZIRMAI Viktória: kutatóprofesszor, MTA Társadalomtudományi Kutatóközpont, Szociológiai Intézet, 1014 Budapest, Úri utca 49; tanszékvezető egyetemi tanár, Kodolányi János Főiskola, Európai Város és Regionális Tanulmányok Intézeti Tanszék, 1139 Budapest, Frangepán u. 50-56.; szirmai.viktoria@tk.mta.hu
\end{abstract}

\begin{abstract}
Viktória SZIRMAI: research professor, Institute for Sociology, Centre for Social Sciences, Hungarian Academy of Sciences; Úri utca 49., H-1014 Budapest, Hungary; head of department, Institutional Department of European Urban and Regional Studies, Kodolányi János University of Applied Sciences; Frangepán u. 50-56., H-1139 Budapest; szirmai.viktoria@tk.mta.hu
\end{abstract}

Horváth Gyula professzor hatására és tanácsára kezdtem el foglalkozni a Kárpát-medence problematikájával. 2015 nyarán Horváth Gyula és Fábián Attila közösen arra kértek, hogy tartsak előadást a Kárpát-medence egy számomra fontos társadalmi kérdésköréről, a soproni Területfejlesztési Szabadegyetem tízéves évfordulója alkalmából rendezett konferencián, illetve készítsek egy tanulmányt a zárókötet számára (Fábián, Bertalan 2015). Ebben az időben fejeztem be a magyar nagyvárostérségi területi egyenlőtlenségek és a társadalmi jól-lét kapcsolatainak az elemzését (Szirmai 2015). Ezért úgy gondoltam, érdemes lenne megvizsgálni a társadalmi jól-lét problematikáját a Kárpát-medence térségeiben is. Emiatt is elfogadtam a felkéréseket, az előadás megtartását és a tanulmány elkészítését.

A számomra szokásos szociológiai ismeretek, különböző kutatási eredmények hiánya miatt a térségi kutatások egyik megszokott módszeréhez nyúltam: országos szintü összehasonlító statisztikai elemzéseket csináltam. Az előadásból készült tanulmány is társadalomstatisztikai alapú volt (Szirmai 2015). Mindehhez segítségül hívtam Gyula számos kötetét: így az ő főszerkesztői munkája alatt készült nagy ívü, átfogó munkákat, a Kárpát-medence régiói sorozat eredményeit

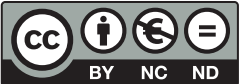


(főszerkesztő: Horváth Gyula). A professzor egyéb munkáira is támaszkodtam, több elemzését átküldte egy ekkor még kidolgozás alatt álló kötetéből, a Kelet- és Közép-Európa régióinak portréi című könyv kéziratából (Horváth 2015a).

Sajnos arra már nem volt módja, hogy megérje a Kelet- és Közép-Európa régióinak portréi című kötet megjelenését, mint ahogy arra sem, hogy részt vegyen a soproni konferencián. ${ }^{1}$ Ezt már nélküle tartottuk meg.

Ez az esemény mélyen megérintett, egyrészt azért, mert a soproni egyetem nagy előadóterme, az ott összegyűltek egyszerre búcsúztak Gyulától, de azért is, mert itt értettem meg, hogy mi mozgatta Horváth professzor akár Erdély, akár a Vajdaság, akár a többi Kárpát-medencei régió iránti tudományos kíváncsiságát. Közvetlenül láttam azt a mély tiszteletet és szeretetet, amely akkor már sajnos csak Gyula emlékének és munkásságának szólt. Sokan érkeztek a Kárpát-medence különböző régióiból és tartottak előadást, elevenítették fel hosszú ideje tartó munkakapcsolataik emlékeit, a közös projekteket. A fiatal részvevők elmondták, hogyan segítette őket akár a doktori értekezésük témaválasztásában, akár a kidolgozás során.

A másik szintén nekem szóló, nem is tanulság, inkább a városszociológusnak releváns megerősítés volt, hogy túl kell lépni a társadalomstatisztikai adatokból kitárulkozó képen és mélyebb, empirikus alapú összefüggéseket kell keresni, helyi szinten kell gondolkodni, elemezni. A Kárpát-medence térségeiből, közte a határ menti országokból érkező előadók szavai mutattak rá a nagy számok mögött rejtőzködő eltérő igazságokra, belső eltérésekre, társadalmi igazságtalanságokra, területi egyenlőtlenségekre.

A konferencia légkörének a hatására is úgy éreztem, folyatnom kell azt a témát, amit Gyula sokak mellett rám is bízott, ezért a soproni konferenciát egy másik, a Magyar Regionális Tudományi Társaság által rendezett egri konferencia követte. Ott már a fiatal csapatommal jelentünk meg, és tartottunk előadást Posztszocialista jól-lét és területi egyenlőtlenségek a Kárpát-medencében címmel. ${ }^{2}$

Horváth Gyula elkötelezetten kutatta a Kárpát-medence országainak belső területi egyenlőtlenségeit. Mégpedig azért, mert úgy vélte, hogy „a területi egyenlőtlenségek politikai feszültségeket keltenek, kedvezőtlen népesedési folyamatokat indítanak el, és tartanak fenn hosszú ideig. Az egyenlőtlenségek mérséklése kiemelten fontos s jelentősen finanszírozott cél nemcsak az Európai Unióban, hanem a világ államainak többségében is. Ám a beavatkozások akkor lehetnek eredményesek, ha hatásaik hosszú távon érvényesülnek, s nem a tüneteket, hanem a hosszú távú folyamatokat próbálják befolyásolni. A folyamatok és az azokra ható tényezők rendkívül sokrétűek, gazdasági, települési, környezeti, társadalmi elemeik vannak. Ezek feltárása, leírása, vizsgálata, a területpolitikai beavatkozások előkészítése a regionális tudomány feladata" (Horváth 2015b, 893.).

Horváth Gyula köztudottan közgazdász indíttatású geográfus volt, ezért a területi egyenlőtlenségek kutatásakor különösképpen érdekelte a gazdasági térszerkezet átalakulása, a történeti egyenlőtlenségek újraéledése, többnyire erősödése, ritkábban a gyengülése. Elemezte a meghatározó okokat: a kialakuló 
piaci társadalom, a demokratikus rendszerek és intézmények, az önkormányzatiság új folyamatainak hatásait, de fontosnak tartotta az európai uniós források érkezésének egyenlőtlenségeket enyhítő szerepét is. Ennél is nagyobb jelentőséget tulajdonított a piaci erőknek, a külföldi működő tőke térségválasztási stratégiáinak, amelyek az EU-s forrásoknál nagyobb mértékben formálják a területi folyamatokat. Ezt számokkal is bizonyította: a kelet- és közép-európai tagállamokhoz az Európai Unió különböző alapjaiból 2000 és 2014 között 200 milliárd euró támogatás érkezett, miközben ugyanebben az időszakban a külföldi múködőtőke-befektetések 660 milliárd eurót hoztak a térségnek (Horváth 2015b, 7.). Közgazdászként sem volt elfogult a piaci erőkkel. Sőt, erőteljesen bírálta a piaci mechanizmusok területi társadalmi hatásait: mivel tudta és tapasztalta, hogy a piaci hatások nem járnak a területi különbségek csökkenésével, hiszen „a piaci befektetések a centrumtérségek fejlődését támogatták, a területi különbségek növelését eredményezték" (uo. 7.). A piaci folyamatok területi következményeit azért is bírálta, mert azok sokszor szembemennek az Európai Unió pénzügyi tranzakciónak a hatásaival és erősítik a területi egyenlőtlenségek rendszereit.

Talán az már kevésbé volt köztudott, hogy közgazdász indíttatású, a társadalom, a társadalmi problémák iránt mélyen elkötelezett geográfus is volt. Ezt nemcsak a konkrét elemzései mutatták: az összes művében, közte a Kárpát-medence sorozatban számos társadalmi dimenziót is a vizsgálat tárgyává tett: például a jövedelmi viszonyokat, a munkanélküliséget, az iskolázottságot, a tudásalapú gazdaság, az oktatás, a tudomány térformáló következményeit (példa erre: Horváth 2015a, 81-101.). Az igazi mutató azonban egy másik jellemzö, mégpedig egyéni beállítottságát, kulturális hátterét, de szakmai felfogását is tükröző egyéni arculat volt: őt nem egyszerüen a szegénység, a kirekesztettség vagy az egyenlőtlenség érdekelte, hanem az, hogy miként lehet abból kikerülni, hogyan lehet egy térség, egy társadalmi csoport viszonyait fejleszteni, a hátrányos helyzetekből kitörni.

Vélhetőleg ebből is adódott, hogy nyitott volt a közgazdaságtan legújabb, a társadalmi összefüggésekre is figyelő irányai felé. Mégpedig azért, mert tudta, hogy a „korábban bevált vizsgálati s alkalmazási eljárások nem egyszerüen azért eredménytelenek, mert rosszul alkalmazzuk azokat, hanem azért is, mert nem napjaink jellemző területi-társadalmi folyamatait igyekszünk befolyásolni, az eszközök ugyanis a korábbi fejlődési adottságokhoz alkalmazkodtak. Fontos alapkutatási feladat a gazdaság és a társadalom térbeli fejlődése új modelljeinek felvázolása” (Horváth 2015b, 7. 893.). Ez az új modell pedig „a GDP-t kiegészíto társadalmi és környezeti mutatók kidolgozására, illetve alkalmazására épül" (uo.). Valószínűleg ezért is fogadta őszinte érdeklődéssel és elismeréssel a mi kísérletünket: hogyan lehet megvizsgálni empirikus módon a stiglitzi jól-létmutatókat a magyar nagyvárosi, illetve vidéki térségi terepeken, hogyan kapcsolható össze a területi és a társadalmi jól-lét-egyenlőtlenségi problematika. Az elismerő mondatokat a Területi egyenlőtlenségektől a társadalmi jól-létig 
című könyv (Szirmai 2015) bemutatóján mondta el, majd később publikálta is (Horváth 2015b, 7.). Úgy éreztem, ezzel is bátorított arra, hogy a soproni elöadást és a tanulmányt, de most az ő emlékére készített írást is a társadalmi jóllét és a területi egyenlőtlenségek tematikájának szenteljem. Mint ahogy az sem véletlen, hogy fiatal szerzőtársaim mellett Fábián Attilát is kértem, vegyen részt munkatársaival a Horváth Gyula tiszteletére készült, itt közreadott Tér és Társadalom lapszám egyik témakörének a kidolgozásában.

A Kárpát-medence társadalmi és gazdasági szerkezete című téma két tanulmányt foglal magában. Az egyik tanulmány a Kárpát-medence posztszocialista országaiban és annak régióiban vizsgálja a társadalmi jól-lét néhány stiglitzi dimenzióját, illetve néhány egyéb társadalmi indikátort is, továbbá a térbeli egyenlőtlenségeket, országos és a regionális léptékű adatok segítségével. A másik tanulmány a társadalmi és gazdasági problémák egyfajta kezelési módját adja meg, a kapacitásfejlesztés, az innováció térségfejlesztő lehetőségeire koncentrálva. Kiderülnek a regionális kapacitásfejlesztés egyes elméleti vonatkozásai is, egyben a kapcsolódási pontok Horváth Gyula munkásságához, elsősorban a regionális és a városi fejlődés hajtóerői, illetve a Kárpát-medence régióinak alakulását befolyásoló térformáló funkciók.

\section{Jegyzetek}

1 Területfejlesztési Szabadegyetem, Otthon a Kárpát-medencében című konferencia (Sopron, 2015. október 8-9.)

2 A Magyar Regionális Tudományi Társaság XIII. Vándorgyűlése, Eger, 2015. november 19-20. Az Egerben elhangzott előadás kidolgozásában részt vettek: Szirmai Viktória, Berki Márton, Halász Levente és Schuchmann Júlia.

\section{Irodalom}

Fábián A., Bertalan L. (szerk.) (2015): Otthon a Kárpát-medencében: Területfejlesztési Szabadegyetem 2011-2015. Nyugat-magyarországi Egyetem Kiadó, Sopron

Horváth Gy. (2015a): Kelet-és Közép-Európa régióinak portréi. Kossuth Kiadó, Budapest

Horváth Gy. (2015b): Életkörülmények eltérő adottságú kistérségekben (könyvszemle). Magyar Tudomány, 7., 893-896.

Szirmai V. (szerk.) (2015): A területi egyenlőtlenségektól a társadalmi jól-lét felé. KJF, Székesfehérvár 